\title{
Phosphogypsum and its potential use in Croatia: challenges and opportunities
}

\author{
Tomislav Bituh, Branko Petrinec, Božena Skoko, Dinko Babić, and Davor Rašeta \\ Institute for Medical Research and Occupational Health, Zagreb, Croatia
}

[Received in November 2020; Similarity Check in November 2020; Accepted in May 2021]

\begin{abstract}
Phosphogypsum (PG) is a waste by-product (residue) originating from the production of phosphoric acid and phosphate fertilisers. PG contains chemical and radioactive impurities, which is why it is mostly stockpiled in controlled areas. Worldwide, only about $15 \%$ of PG is recycled or reused. Today, policies and business strategies prioritise sustainable development through circular economy, which certainly includes PG. This provides new opportunities for Croatia to manage its PG and make an effort to use it as an additive in different industries, such as agriculture and construction. Due to its chemical and radiological properties, PG can potentially cause problems for the environment and human health. Hence, before using PG, detailed knowledge of potential hazards is necessary to protect people and the environment. The aim of this review is to summarise available data on Croatian PG, compare them with other countries, and to identify knowledge gaps and the lack of data on potential hazardous substances in PG in order to assess the opportunities of using PG in Croatia.
\end{abstract}

KEY WORDS: circular economy; heavy metals; NORM; radioactivity; radionuclides; reuse

Minerals and ores exploited from the Earth's crust contain naturally occurring radionuclides. In industrial processing, these radionuclides can become concentrated in by-products. Depending on the level of activity concentrations of radionuclides, some of these by-products can be considered as naturally occurring radioactive materials (NORM). The International Atom Energy Agency (IAEA) defines NORM as "radioactive material containing no significant amounts of radionuclides other than naturally occurring radionuclides (including materials in which activity concentrations have been changed by a process)" (1). Some examples of NORM include fly ash from coal burning, slags from different recycling industries, and red mud from aluminium processing. The subject of this review is a by-product (residue) of phosphoric acid production known as phosphogypsum (PG), mostly composed of $\mathrm{CaSO}_{4}$ × $2 \mathrm{H}_{2} \mathrm{O}(95 \%)$.

Due to its high activity concentration of natural radionuclides $P G$ is classified as $\operatorname{NORM}(2,3)$ or technologically enhanced naturally occurring radioactive material (TENORM), according to the US Environmental Protection Agency (EPA). "Technologically enhanced", according to EPA, "means that the radiological, physical, and chemical properties of the radioactive material have been concentrated or further altered by having been processed, or beneficiated, or disturbed in a way that

Corresponding author: Tomislav Bituh, Institute for Medical Research and Occupational Health, Radiation Protection Unit, Ksaverska cesta 2, HR-10000 Zagreb, Croatia, E-mail: tbituh@imi.hr increases the potential for human and/or environmental exposures" (4).

Potential issues of concern resulting from phosphogypsum disposal are its environmental impacts, i.e. possible increases in radionuclide concentrations in soil or groundwater and consequent ingestion by humans through drinking water and food (3). Once deposited in the bone tissue, ${ }^{226} \mathrm{Ra}$ (which is the dominant radionuclide in $\mathrm{PG}$ ) can cause biological damage through continuous irradiation of human skeleton over many years and may induce bone sarcoma $(3,5)$. Of additional concern is the inhalation of ${ }^{222} \mathrm{Rn}$ (daughter radionuclide of ${ }^{226} \mathrm{Ra}$ ), especially in occupational setting, which increases the internal dose.

Phosphate products are manufactured by either wet or thermal processing. Wet dihydrate processing involves the treatment of a phosphate rock with concentrated sulphuric acid at $75-80^{\circ} \mathrm{C}$ to obtain phosphoric acid and $\mathrm{PG}$ as a by-product (6). Wet processing produces around 4-6 tonnes of $\mathrm{PG}$ per tonne of $\mathrm{P}_{2} \mathrm{O}_{5}(3,7-9)$. The chemical reaction for the process is given in Eq. 1, as follows:

$\mathrm{Ca}_{10}\left(\mathrm{PO}_{2}\right)_{6} \mathrm{~F}_{2}+10 \mathrm{H}_{2} \mathrm{SO}_{4}+20 \mathrm{H}_{2} \mathrm{O} \rightarrow 6 \mathrm{H}_{3} \mathrm{PO}_{4}+10\left(\mathrm{CaSO}_{4} \times 2 \mathrm{H}_{2} \mathrm{O}\right)+2 \mathrm{HF}$

(Eq. 1)

In Croatia, phosphoric acid had been produced by a fertiliser company Petrokemija from 1983 to 2009. During that period, around $8.5 \mathrm{Mt}$ of PG was produced. (10). PG was transported to a disposal site as slurry by pipelines some $4 \mathrm{~km}$ to the south of the factory. The disposal site borders the Lonjsko Polje Nature Park, an ornithological reserve and floodplain area covering 50.650 ha (Figure 1).

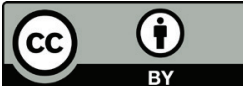



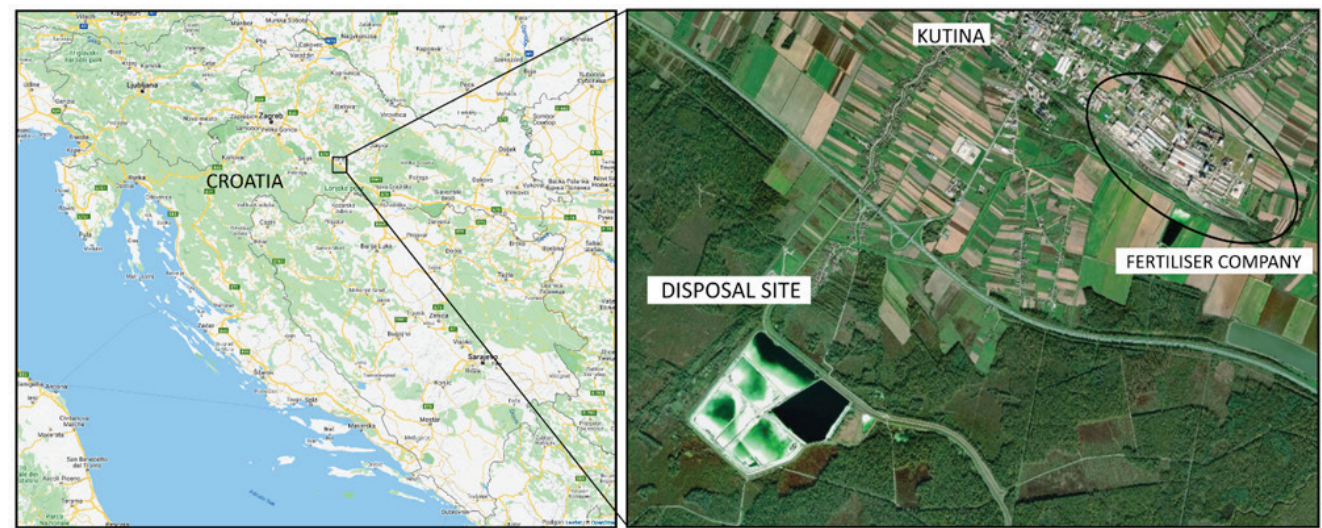

Figure 1 Location of the phosphogypsum disposal site in relation to the fertiliser factory and the city of Kutina, Croatia

The disposal site consists of five ponds and has a surface of $1.7 \mathrm{~km}^{2}$ and average depth of $4 \mathrm{~m}$. The embankment dams (clay) surrounding the disposal site are constructed in such a way as to protect the surrounding environment. The potential impact of PG on the environment has already been investigated $(7,8,11,12)$, and the company in charge of maintenance of the site is monitoring groundwater levels on a regular basis.

The objective of this review is to summarise the available data on $\mathrm{PG}$ properties, compare Croatian PG with worldwide reports, and provide an integrated, multidisciplinary knowledge base that could help assess the opportunities of using Croatian PG in building and construction industry or agriculture in the near future. The potential use of PG includes detailed analysis from chemical, radiological, and structural perspective. In this sense, our review should inform future management of Croatian PG and potential users (agriculture and construction industry).

Our literature search includes up-to-date knowledge about PG use over the last 15 years, with a few exceptions published in the 1990s and before. Additionally, several books published by the IAEA were used as a source of summarised data.

\section{PHYSICO-CHEMICAL CHARACTERISTICS OF PHOSPHOGYPSUM}

Phosphogypsum is a grey, damp, fine-grained material (silty or silty-sandy) with a maximum grain size between 0.5 and $1.0 \mathrm{~mm}$ and $50-75 \%$ of particles finer than $0.075 \mathrm{~mm}(6)$. The moisture content usually ranges between $8 \%$ and $30 \%(3,6)$. Its density, strength, compressibility, and permeability (hydraulic conductivity) are influenced by disposal method and depth within a stack. Because of the homogeneity of PG particles, the process of stacking causes the material to become compacted over time. This is the reason why its density and strength increase over time, while permeability and compressibility decrease (3).

Its chemical composition depends on the origin and chemical treatment of the phosphate rock. PG obtained by wet processing is mostly composed of $\mathrm{CaSO}_{4} \times 2 \mathrm{H}_{2} \mathrm{O}$ $(95 \%)$ or $\mathrm{CaSO}_{4} \times 1 / 2 \mathrm{H}_{2} \mathrm{O}$ (in the hemihydrate process). Multiple authors list impurities such as $\mathrm{H}_{3} \mathrm{PO}_{4}$, $\mathrm{Ca}\left(\mathrm{H}_{2} \mathrm{PO}_{4}\right)_{2} \times \mathrm{H}_{2} \mathrm{O}, \mathrm{CaHPO}_{4} \times 2 \mathrm{H}_{2} \mathrm{O}$ and $\mathrm{Ca}_{3}\left(\mathrm{PO}_{4}\right)_{2}$, residual acids, fluorides ( $\mathrm{NaF}, \mathrm{Na}_{2} \mathrm{SiF}_{6}, \mathrm{Na}_{3} \mathrm{AlF}_{6}, \mathrm{Na}_{3} \mathrm{FeF}_{6}$ and $\left.\mathrm{CaF}_{2}\right)$, sulphate ions, trace metals $(\mathrm{Cr}, \mathrm{Cu}, \mathrm{Zn}$, and $\mathrm{Cd})$, and organic matter such as aliphatic compounds of carbonic acids, amines, and ketones, all of which adhere to the surface of the gypsum crystals $(2,3,13,14)$.

The propagation of radionuclides in fertiliser production depends on the chemical properties of U, Ra, and Th. Most of ${ }^{238} \mathrm{U}$ and ${ }^{232} \mathrm{Th}$ enter the fertiliser, and most of ${ }^{226} \mathrm{Ra}$ is incorporated into $\mathrm{PG}(2,8,9)$. During wet processing, about $80 \%$ of ${ }^{226} \mathrm{Ra}, 30 \%$ of ${ }^{232} \mathrm{Th}$, and $14 \%$ of ${ }^{238} \mathrm{U}$ is concentrated in $\mathrm{PG}$, while the rest ends up in phosphoric acid in fertilisers $(13,15,16)$, which is why the radiological risk of PG is mainly associated with exposure to ${ }^{226} \mathrm{Ra}\left(\mathrm{t}_{1 / 2}=1600\right.$ years) and its decay products.

According to Rutherford et. al (2), ${ }^{226}$ Ra probably does not occupy regular lattice positions within U-bearing materials. Whereas $\mathrm{U}^{4+}(\mathrm{IR}=0.097 \mathrm{~nm})$ often replaces $\mathrm{Ca}^{2+}$ $(\mathrm{IR}=0.099 \mathrm{~nm})$ in apatite due to the similarity of ionic radii, the ionic radius of $\mathrm{Ra}^{2+}(\sim 0.152 \mathrm{~nm})$ is too large for the isomorphous replacement of $\mathrm{Ca}^{2+}$. It is therefore likely that $\mathrm{Ra}$ from phosphorite is co-precipitated with $\mathrm{Ba}$ and/or $\mathrm{Sr}$ as a sulphate compound. PG formation is a dynamic process, in which foreign ions enter the calcium sulphate phase during crystal growth. Since this growth never takes place in equilibrium conditions in an industrial process, radionuclide incorporation into phosphogypsum is a complex mechanism affected by many factors (17).

The fact that ${ }^{226} \mathrm{Ra}$ is more closely associated with the finer hemihydrate particles than the large dihydrate particles in PG is the basis for procedures designed to lower the radioactivity of $P G(2,18)$.

\section{RADIOLOGICAL CHARACTERISTICS OF PHOSPHOGYPSUM}

The concentrations of naturally occurring radionuclides in phosphate rock depend on the origin of the rock. The 
largest world deposits of phosphate rock are in Morocco, South Africa, Florida, China, India, and Egypt (8). Total global phosphate deposits are estimated to 163 billion tonnes. Most of these deposits are of sedimentary origin, with as little as $4 \%$ being of igneous origin (e.g. on the Kola Peninsula, Russia). In Croatian petrochemical industry, most of the phosphate rock used was of sedimentary origin and came from Morocco (8).

A detailed radionuclide measurement at the $\mathrm{PG}$ disposal site in 2015 (11) including in-depth samples showed that the activity concentrations of ${ }^{226} \mathrm{Ra}$ ranged from 473 to $1626 \mathrm{~Bq} / \mathrm{kg}$, with average values of $811 \mathrm{~Bq} / \mathrm{kg}$. These findings are in accordance with the worldwide data. Table 1 shows that activity concentrations of ${ }^{226} \mathrm{Ra},{ }^{232} \mathrm{Th}$, and ${ }^{40} \mathrm{~K}$ found in PG from Croatia are different from most countries. In some cases, ${ }^{226} \mathrm{Ra}$ activity concentrations are even twice as high (except in comparison with the UK), whereas those of ${ }^{232} \mathrm{Th}$ and ${ }^{40} \mathrm{~K}$ are much lower (except in comparison with Romania and the UK). The reason for this could be different origin of the phosphate rock as well as different chemical process.

In Croatia, the main radiological concerns about $\mathrm{PG}$ are its storage (disposal) and potential use in construction industry and agriculture. At high activity concentrations of ${ }^{226} \mathrm{Ra}$, both involve the risk of exposure to gamma radiation and inhalation of its gaseous daughter radionuclide ${ }^{222} \mathrm{Rn}$ and its decay products (19). Namely, of the three radon (Rn) isotopes naturally present in the environment, ${ }^{222} \mathrm{Rn}$ with its half-life $\left(\mathrm{t}_{1 / 2}\right)$ of 3.82 days (as opposed to $55.6 \mathrm{~s}$ of ${ }^{220} \mathrm{Rn}$ and $3.98 \mathrm{~s}$ of ${ }^{219} \mathrm{Rn}$ ) and much higher activity concentrations, is the most important from the radiological point of view. Namely, ${ }^{222} \mathrm{Rn}$ accounts for about $50 \%$ of the total effective dose from all natural and man-made sources received by the general population $(23,24)$. Higher concentrations of ${ }^{226} \mathrm{Ra}$ as the parent radionuclide of ${ }^{222} \mathrm{Rn}$ in $\mathrm{PG}$ increase radon release and, consequently, inhalation from air, especially in occupational settings.

Because radon is an inert gas, it can move rather freely through porous media such as building materials, although usually only a fraction of ${ }^{222} \mathrm{Rn}$ reaches the surface of the material and enters indoor air (24), whereas the other two $\mathrm{Rn}$ isotopes decay before they reach the surface of the material. Due to the long half-life of ${ }^{226} \mathrm{Ra},{ }^{222} \mathrm{Rn}$ is released constantly and can accumulate in poorly ventilated spaces, increasing the risk of exposure to higher doses.

\section{HEAVY METALS IN PHOSPHOGYPSUM}

Heavy metal and rare earth element (REE) concentrations in PG depend on the composition and the origin of the phosphate rock. Detailed investigations of Moroccan phosphate rock and PG in Huelva, Spain (25) showed that only $2-12 \%$ of trace elements from phosphate rock are transferred into PG, with the exception for $\mathrm{Sr}(66 \%)$, Ce (56\%), Y (41\%) and $\mathrm{Pb}(27 \%)$ (25). Relying on their research of Tunisian phosphate rock, Zmemla et al. (26) suggested three levels of metal mobility: high ( $\mathrm{Sr}$ and $\mathrm{Zn}$ ), moderate mobility (As, $\mathrm{Ba}, \mathrm{Cd}$, and $\mathrm{Cr}$ ), and low $(\mathrm{Cu}, \mathrm{Ni}$, $\mathrm{Pb}, \mathrm{Se}, \mathrm{V}, \mathrm{Y}$, and $\mathrm{Zr}$ ).

Table 2 compares typical ranges of metal concentrations in Croatian PG reported by Franković Mihelj et al. (27) and Leaković et al. (28) with concentrations reported for other countries by the IAEA (3). Data on most of the heavy metals and REEs in Croatian PG are lacking and remain to be established by future investigations. Other elements show lower levels compared to other countries, which makes Croatian PG more eligible for use in agriculture.

Table 1 Comparison of average activity concentrations of natural radionuclides $\left({ }^{226} \mathrm{Ra},{ }^{232} \mathrm{Th},{ }^{40} \mathrm{~K}\right)$ in phosphogypsum between Croatia and other countries (ranges in parentheses)

\begin{tabular}{|c|c|c|c|c|}
\hline Country & ${ }^{226} \mathrm{Ra}(\mathrm{Bq} / \mathrm{kg})$ & ${ }^{232} \mathrm{Th}(\mathrm{Bq} / \mathrm{kg})$ & ${ }^{40} \mathrm{~K}(\mathrm{~Bq} / \mathrm{kg})$ & Reference \\
\hline Croatia & $811(473-1626)$ & $8(3-15)$ & $13(7-23)$ & (12) \\
\hline Belgium & $431(420-442)$ & $11(10-11)$ & & \multirow{12}{*}{$(10,19,20)$} \\
\hline Bulgaria & $209(18-400)$ & $17(9-25)$ & $3(1-5)$ & \\
\hline Czech Republic & 115 & 31 & 95 & \\
\hline Finland & $306(24-830)$ & $23(3-118)$ & $17(9-30)$ & \\
\hline Germany & $305(60-550)$ & $20(20-20)$ & 110 & \\
\hline Greece & $606(547-642)$ & $10(2-19)$ & $22(0-41)$ & \\
\hline The Netherlands & $223(28-450)$ & $24(9-48)$ & $50(16-120)$ & \\
\hline Poland & $267(61-381)$ & $17(7-28)$ & $72(41-109)$ & \\
\hline Romania & $497(155-702)$ & $40(9-89)$ & $242(44-569)$ & \\
\hline Slovenia & 500 & 10 & 41 & \\
\hline Serbia & $600(488-737)$ & $3(2-5)$ & $47(5-117)$ & \\
\hline United Kingdom & $1018(629-1406)$ & $33(19-48)$ & $130(41-218)$ & \\
\hline USA & $750(270-1353)$ & 1 & 14 & $(10,21,22)$ \\
\hline
\end{tabular}




\section{THE USE OF PHOSPHOGYPSUM}

Considering that the annual rate of $\mathrm{PG}$ stacking worldwide is around 130 million tonnes (40 mil. in the USA and 90 mil. elsewhere) (3), numerous investigations are focused on new uses for this low-cost waste (25). The main focus is on its use as an additive to agricultural soils, as an additive in ettringite-based binders, and as raw material in plaster bricks, masonry walls, road base binders, sodium sulphate, soil limestone, and ammonium sulphate. However, these uses are limited by the high content of toxic impurities, and only $15 \%$ of the worldwide production is recycled. The remaining $85 \%$ requires large disposal areas and may cause huge environmental problems. Other potential applications of PG include mine reclamation or sulphur recovery. However, we will not address them here, as they have no potential in Croatia.

Hilton (29) proposes four main critical success factors for using PG: technical feasibility, regulatory acceptability, commercial sustainability, and political will. Only if all four conditions are met, the PG "problem" will be solved. In terms of technical feasibility, PG can replace natural gypsum in different products and applications. The sustainability factor is met through much lower cost of PG in relation to natural gypsum. However, regulatory aspects are yet to be solved, as radiation protection remains one of the main concerns about PG use.

\section{Phosphogypsum in construction industry}

There are numerous ways and technologies to reuse by-products/residues in construction industry, most notably in Portland cement (both as cement and concrete), alkaliactivated cement and concrete (geopolymers), ceramics and glass-ceramics, and gypsum, phosphogypsum in particular.

Gypsum (hydrous calcium sulphate) is a common raw material used in the production of plasters, drywalls, ceiling tiles, and building blocks. As a raw material, gypsum comes in two forms: as natural gypsum stone and as synthetic gypsum (by-product of some industrial processes). The latter has largely replaced natural gypsum to reduce exploitation and damage to the environment (9). Since PG is very similar to natural gypsum, it can replace it in building products. The main challenge, however, is high radon release and higher concentrations of ${ }^{226} \mathrm{Ra}$. In Portland cement PG is used as a setting time retarder in amounts below 4-5\% (30). Once diluted in the concrete ${ }^{226}$ Ra activity concentration does not present an issue, but radon release is increased, as exposure to ${ }^{222} \mathrm{Rn}$ depends on material thickness and density besides ${ }^{226} \mathrm{Ra}$ concentration (31). The reason of high ${ }^{222} \mathrm{Rn}$ release (around $50 \%$ ) is its microstructure and porosity of the building material. Gypsum crystals are usually longitudinal (fibroid) in shape with large surface area, while overall density of gypsum products is usually low, $800-1200 \mathrm{~kg} / \mathrm{m}^{3}$, which is why radon is easily released $(9,31)$.

Croatian regulation for all NORM materials that can be used in construction relies on the activity concentration index as a conservative screening tool for identifying materials that exceed reference levels (32). This index relates to indoor gamma radiation dose in a building constructed from a specified building material in excess of typical outdoor exposure. It applies to the building material

Table 2 Typical element concentration ranges in PG from different countries compared to Croatian PG

\begin{tabular}{|c|c|c|c|c|c|}
\hline \multirow{2}{*}{ Trace element } & \multicolumn{2}{|c|}{ Concentration range (mg/kg) } & \multirow{2}{*}{ Trace element } & \multicolumn{2}{|c|}{ Concentration range $(\mathrm{mg} / \mathrm{kg})$} \\
\hline & $\begin{array}{c}\text { Worldwide data } \\
\text { (3) }\end{array}$ & Croatian PG & & $\begin{array}{l}\text { Worldwide data } \\
\text { (3) }\end{array}$ & Croatian PG \\
\hline $\mathrm{Ag}$ & $0.4-5$ & & $\mathrm{Na}$ & & $0.008-0.010$ \\
\hline $\mathrm{Al}$ & & $0.04-0.1$ & $\mathrm{Nd}$ & $30-67$ & \\
\hline As & $1-42$ & $<0.05$ & $\mathrm{Ni}$ & $1.7-250$ & $<1$ \\
\hline $\mathrm{Ba}$ & $20-236$ & 5 & $\mathrm{~Pb}$ & $0.5-16$ & $<1$ \\
\hline $\mathrm{Cd}$ & $0.8-40$ & 0.002 & $\mathrm{Sb}$ & & $<0.05$ \\
\hline $\mathrm{Ce}$ & $21-143$ & & $\mathrm{Se}$ & $0.5-75$ & $<0.05$ \\
\hline $\mathrm{Co}$ & $0.05-2.3$ & & $\mathrm{Sm}$ & $5-13$ & \\
\hline $\mathrm{Cr}$ & $1.6-75$ & $<0.5$ & $\mathrm{Sr}$ & $10-1118$ & \\
\hline $\mathrm{Cu}$ & $2-195$ & $<0.5$ & Th & $0.4-4$ & \\
\hline $\mathrm{Eu}$ & $1.1-3$ & & $\mathrm{Ti}$ & $26-470$ & \\
\hline $\mathrm{Fe}$ & & $90-450$ & $\mathrm{U}$ & $0.5-13.8$ & \\
\hline $\mathrm{Hg}$ & $0.005-10$ & 0.02 & $\mathrm{~V}$ & $2-40$ & \\
\hline $\mathrm{La}$ & $42-90$ & & $\mathrm{Y}$ & $2-156$ & \\
\hline $\mathrm{Lu}$ & $0.3-0.4$ & & $\mathrm{Yb}$ & $2.1-3.2$ & \\
\hline $\mathrm{Mn}$ & $3.5-20$ & & $\mathrm{Zn}$ & $4-315$ & 3.23 \\
\hline Mo & $1-16$ & & $\mathrm{Zr}$ & $10-110$ & \\
\hline
\end{tabular}


and not to its constituents, except when those constituents are building materials themselves and are separately assessed as such.

Considerations to use PG as building material in construction industry should therefore rely on the activity concentration index as calculated with Equation 2:

$$
I=\frac{C_{R a}}{300 \mathrm{~Bq} / \mathrm{kg}}+\frac{C_{T h}}{200 \mathrm{~Bq} / \mathrm{kg}}+\frac{C_{K}}{3000 \mathrm{~Bq} / \mathrm{kg}}
$$

(Eq. 2)

where $\mathrm{C}_{\mathrm{Ra}}, \mathrm{C}_{\mathrm{Th}}, \mathrm{C}_{\mathrm{K}}$ are activity concentrations $(\mathrm{Bq} / \mathrm{kg})$ of ${ }^{226} \mathrm{Ra},{ }^{232} \mathrm{Th}$, and ${ }^{40} \mathrm{~K}$ in a building material. The index serves to determine whether gamma radiation in a building exceeds $1 \mathrm{mSv}(18,33)$. Additionally, depending on the dose criterion and the amount of material to be used, the activity concentration index should not exceed the values given in Table 3.

If we entered the average ${ }^{226} \mathrm{Ra},{ }^{232} \mathrm{Th}$, and ${ }^{40} \mathrm{~K}$ activity concentrations measured in Croatian PG (Table 1) into Eq. 2 , this index would be 2.748 , and maximum permitted percentage of $\mathrm{PG}$ in construction material would be $36 \%$. In the worst-case scenario (with the highest activity concentrations) only $18 \%$ of PG could be incorporated into building material.

In its Radiological Protection Principles concerning the Natural Radioactivity of Building Materials of 1999 (33), the European Commission recommends that the activity concentration index should be used only as a screening tool for identifying materials of concern. Any actual decision to restrict the use of a material should, however, rely on a separate dose assessment based on scenarios in which the material is used in a typical way. Scenarios resulting in unlikely maximum doses should be avoided.

Purification of PG in materials that exceed acceptable radiation levels is too expensive to justify the production cost, and is therefore not an option. Such PGs are simply not considered for use in construction.

\section{Phosphogypsum in agriculture}

PG has been used on agricultural land since the 1980s to replace limestone in improving saline and alkali soils $(34,35)$. More specifically, it has been used in highly weathered nutrient-poor soils, in alkali soils with dense subsoil horizons or those prone to dispersion and crusting at the surface, in acid soils with high aluminium levels, and in calcareous soils (2).

However, this kind of use raises concerns about natural radioactivity, heavy metal contamination, effects on soil nutrients, and leaching of pollutants into groundwater. A review article by Mesić et al. (36) gives a comprehensive insight into the benefits and environmental risks associated with the application of $P G$ in agriculture, which acknowledges the complexity of the issue but also suggests that the benefits can prevail, provided that every country should conduct their own research to address the specifics of their agroecosystems.

A study by Elloumi et al. (37) on the effects of PG on sunflower seeds also addresses the benefits and risks in a comprehensive way and suggests that co-application with various other organic and inorganic materials, such as lime, gypsum, animal manure, sewage sludge, composts, biochar, or bioinoculants could improve nutrient availability, reduce salinity, buffer $\mathrm{pH}$, and improve the general health of the soil. At the same time, it points out the risks of toxicity in plants posed by heavy metals present in PG, Cd in particular, as it generates oxidative stress.

In addition, an investigation by Abril et al. (34) showed that there is a positive correlation between $\mathrm{Cd}$ and ${ }^{226} \mathrm{Ra}$ levels in PG accumulated over the years of application. The increase in Cd levels was confirmed by Enamorado et al. (38), who concluded that each $\mathrm{kg}$ of PG adds $2.1 \mathrm{mg}$ of $\mathrm{Cd}$ to the soil.

All this suggests that before PG is used in agriculture, it should be analysed for trace elements to avoid transfer of harmful elements to food and consequently exceed their regulatory limits in food products.

\section{REGULATORY ASPECTS AND OPORTUNITIES FOR PHOSPHOGYSUM USE IN CROATIA}

Gradual changes in the EU regulatory approach to natural radioactivity in building materials are described in detail in Schroeyers (9). Annex XIII of the EU Council Directive 2013/59/EURATOM (39) provides an indicative list of building materials of concern, divided into natural materials and materials incorporating residues from NORM processing industries. In article 75, the Directive sets the reference limit for indoor external exposure to gamma radiation from building materials to $1 \mathrm{mSv}$ per year above outdoor external exposure. In Croatia, the use of NORM as part of building material is regulated by article 41 of the Ordinance on environmental monitoring of radioactivity (32), based on activity concentration index. As explained above, this index relates to indoor gamma radiation dose in a building constructed from a specified building material which exceeds typical outdoor exposure. However, the use of PG in agriculture has not been regulated yet.

Table 3 Dose criterion for activity concentration index for different products

\begin{tabular}{lcc}
\hline Dose criterion & $\mathbf{0 . 3} \mathbf{~ m S v} /$ year & $\mathbf{1 ~ m S v / y e a r}$ \\
\hline Materials used in bulk: concrete & $\mathrm{I} \leq 0.5$ & $\mathrm{I} \leq 1$ \\
\hline $\begin{array}{l}\text { Superficial and other materials with restricted use: tiles, } \\
\text { boards etc. }\end{array}$ & $\mathrm{I} \leq 2$ & $\mathrm{I} \leq 6$ \\
\hline
\end{tabular}


In addition, the Ordinance on the conditions and measures of ionising radiation protection for performing activities involving ionising radiation sources (40) sets the activity concentration limits for materials, including PG, that are exempt from its regulatory supervision. The activity concentrations for the exemption of ${ }^{226} \mathrm{Ra}$ (and its progenies) and ${ }^{40} \mathrm{~K}$ are $10 \mathrm{kBq} / \mathrm{kg}$ and $100 \mathrm{kBq} / \mathrm{kg}$, respectively. In line with these regulatory exemptions the Radioactive Waste, Disused Sources and Spent Nuclear Fuel Disposal Strategy (41) encourages management of by-products with activity concentrations below regulatory limits and their reuse, including PG generated from the production of mineral fertilisers, which could be used for the production of building materials.

However, the Waste Management Plan of the Republic of Croatia for 2007-2015 (42) and 2017-2022 (43) does not foresee PG reuse in any form, as it only speaks of remediation and closing of the disposal site in Kutina.

Hilton (29), in turn, provides an interesting view on regulatory approach to $\mathrm{PG}$ (re)use, which should be transparent, consistent globally across regulatory and safety standards for evidence-based decision-making, and involve cooperation between local/regional governments, centres of excellence, local and international industry, customers, and local communities. Croatia can accommodate most of the principles proposed by Hilton (29) and work more on cooperation between the government, centres of excellence, industry, and community.

The PG disposal site in Kutina changed the owner in 2019. The new company faces new management challenges to be profitable but it also has the opportunity to offer PG as a low-cost material for various producers. The main target groups are national and international construction companies that use PG as additive for different materials.

In addition, the company has received inquiries from the agricultural sector to provide $\mathrm{PG}$ as an additive to compost for mushroom growth. Mushrooms are usually grown on compost mixed with natural gypsum, which provides optimal $\mathrm{pH}$ and $\mathrm{Ca}$. There are some indications that natural gypsum could be replaced by PG, which would lower production costs. To the best of our knowledge, such use has not been covered by scientific research, which raises a number of concerns, including those about PG use in food production. Namely, it is considered justifiable in some countries and restricted in others (3). Croatia has not regulated this issue explicitly but relies on the dose limit of $1 \mathrm{mSv} /$ year above outdoor external exposure defined by the EU Council Directive 2013/59/EURATOM (39), the EU Council Directive 2006/52/EURATOM (44) which lays down the maximum permitted levels of radioactive contamination of food, and the Ordinance on notification, registration, approval and placing on the market of sources of ionising radiation (45), which includes even such activities with ionising radiation sources such as NORM that are otherwise exempt if they may raise concern about the presence of natural radionuclides in drinking water and food. In this sense, a positive public opinion survey could be an advantage in obtaining a license for using PG in food production. Additionally, concerning heavy metals, food production is also monitored by the other competent authority - the Ministry of Health.

\section{CONCLUSION}

With its PG stacked at a disposal site near Lonjsko Polje Nature Park, Croatia has yet to carefully weigh the risks and benefits of its reuse. Parties interested in its reuse include the managing company, users (construction industry and agriculture), and local inhabitants. In fact, the use of Croatian PG in construction industry is the most promising option for PG management at the moment, as agricultural use has not been nearly as investigated and regulated, and detailed studies are needed for each specific scenario. Further research should also focus on heavy metals and REEs in PG.

\section{REFERENCES}

1. International Atomic Energy Agency (IAEA). IAEA Safety Glossary: 2018 Edition [displayed 22 April 2021]. Available at https://www-pub.iaea.org/MTCD/Publications/PDF/ PUB1830_web.pdf

2. Rutherford PM, Dudas MJ, Samek RA. Environmental impacts of phosphogypsum. Sci Total Environ 1994;149:138. doi: 10.1016/0048-9697(94)90002-7

3. International Atomic Energy Agency (IAEA). Radiation Protection and Management of NORM Residues in the Phosphate Industry. No. 78, 2013 [displayed 22 April 2021]. Available at https://www-pub.iaea.org/MTCD/Publications/ PDF/Pub1582_web.pdf

4. United States Environmental Protection Agency (US EPA). Technologically Enhanced Naturally Occurring Radioactive Materials (TENORM). US EPA [displayed 22 April 2021]. Available at https://www.epa.gov/radiation/technologicallyenhanced-naturally-occurring-radioactive-materials-tenorm

5. Marović $\mathrm{G}$, Senčar J. ${ }^{226} \mathrm{Ra}$ and possible water contamination due to phosphate fertilizer production. J Radioanal Nucl Chem 1995;200:9-18. doi: 10.1007/BF02164816

6. Saadaoui E, Ghazel N, Ben Romdhane C, Massoudi N. Phosphogypsum: potential uses and problems-a review. Int J Environ Stud 2017;74:558-67. doi: 10.1080/00207233.2017.1330582

7. Bituh T, Vučić Z, Marović G, Prlić I. A new approach to determine the phosphogypsum spread from the deposition site into the environment. J Hazard Mater 2013;261:584-92. doi: 10.1016/j.jhazmat.2013.08.012

8. Bituh T, Marović G, Franić Z, Senčar J, Bronzović M. Radioactive contamination in Croatia by phosphate fertilizer production. J Hazard Mater 2009;162:1199-203. doi: 10.1016/j.jhazmat.2008.06.005

9. Schroeyers W, editor. Naturally Occurring Radioactive Materials in Construction: Integrating Radiation Protection in Reuse (COST Action TU1301 NORM4BUILDING), 2017, Cambridge: Woodhead Publishing; 2017. 
10. Odluka o donošenju Nacionalnog programa provedbe Strategije zbrinjavanja radioaktivnog otpada, iskorištenih izvora $\mathrm{i}$ istrošenog nuklearnog goriva (Program za razdoblje do 2025. godine s pogledom do 2060. godine) [National program on implementation of Radioactive Waste, Disused Sources and Spent Nuclear Fuel Disposal Strategy In Croatia (Program for period until 2025 with overview on 2060), in Croatian]. Narodne novine 100/2018.

11. Bituh T, Petrinec B, Skoko B, Vučić Z, Marović G. Measuring and modelling the radiological impact of a phosphogypsum deposition site on the surrounding environment. Arh Hig Rada Toksikol 2015;66:31-40. doi: 10.1515/aiht-2015-662587

12. Tayibi H, Choura M, López FA, Alguacil FJ, López-Delgado A. Environmental impact and management of phosphogypsum. J Environ Manage 2009;90:2377-86. doi: 10.1016/j. jenvman.2009.03.007

13. Rutherford PM, Dudas MJ, Arocena JM. Heterogeneous distribution of radionuclides, barium and strontium in phosphogypsum by-product. Sci Total Environ 1996;180:2019. doi: 10.1016/0048-9697(95)04939-8

14. Mas JL, San Miguel EG, Bolívar JP, Vaca F, Perez-Moreno JP. An assay on the effect of preliminary restoration tasks applied to a large TENORM wastes disposal in the south-west of Spain. Sci Total Environ 2006;364:55-66. doi: 10.1016/j. scitotenv.2005.11.006

15. Bolívar JP, Martín JE, García-Tenorio R, Pérez-Moreno JP, Mas JL. Behaviour and fluxes of natural radionuclides in the production process of a phosphoric acid plant. Appl Radiat Isot 2009;67:345-56. doi: 10.1016/j.apradiso.2008.10.012

16. Beretka J, Mathew PJ. Natural radioactivity of Australian building materials, industrial wastes and by-products. Health Phys 1985;48:87-95. doi: 10.1097/00004032-19850100000007

17. Szajerski P. Distribution of uranium and thorium chains radionuclides in different ractions of phosphogypsum grains. Environ Sci Pollut Res 2020;27:15856-15868. doi: 10.1007/ s11356-020-08090-y

18. Trevisi R, Risica S, D’Alessandro M, Paradiso D, Nuccetelli C. Natural radioactivity in building materials in the European Union: a database and an estimate of radiological significance. J Environ Radioact 2012;105:11-20. doi: 10.1016/j. jenvrad.2011.10.001

19. Kuzmanović P, Todorović N, Forkapić S, Petrović LF, Knežević J, Nikolov J, Miljević B. Radiological characterization of phosphogypsum produced in Serbia. Radiat Phys Chem 2020;166:108463. doi: 10.1016/j. radphyschem.2019.108463

20. Roper AR, Stabin MG, Delapp RC, Kosson DS. Analysis of naturally-occurring radionuclides in coal combustion fly ash, gypsum, and scrubber residue samples. Health Phys 2013;104:264-9. doi: 10.1097/HP.0b013e318279f3bf

21. Hull CD, Burnett WC. Radiochemistry of Florida phosphogypsum. J Environ Radioact 1996;32:213-38. doi: 10.1016/0265-931X(95)00061-E

22. Ishimori Y, Lange K, Martin P, Mayya YS, Phaneuf M. Measurement and Calculation of Radon Releases from NORM Residues. Techn Rep Ser No. 474, 2013 [displayed 22 April 2021]. Available at https://www-pub.iaea.org/ MTCD/Publications/PDF/trs474_webfile.pdf

23. United Nations Scientific Committee on the Effects of Atomic Radiation (UNSCEAR). Sources and Effects of Ionizing
Radiation - Annex B. Exposures from natural radiation sources. Vol. I. New York: Unitet Nations; 2010.

24. Kovler K. Radioactive materials. Chapter 8. In: Torgal FP, Jalali S, Fucic A, editors. Toxicity of building material. Cambridge: Woodhead Publishing Limited; 2012, p. 196240.

25. Pérez-López R, Nieto JM, López-Coto I, Aguado JL, Bolívar JP, Santisteban M. Dynamics of contaminants in phosphogypsum of the fertilizer industry of Huelva (SW Spain): From phosphate rock ore to the environment. Appl Geochemistry 2010;25:705-15. doi: 10.1016/j. apgeochem.2010.02.003

26. Zmemla R, Chaurand P, Benjdidia M, Elleuch B, Yves J. Characterization and $\mathrm{pH}$ dependent leaching behavior of Tunisian phosphogypsum. Am Sci Res J Eng Technol Sci 2016;24:230-44.

27. Franković Mihelj N, Ukrainczyk N, Leaković S, Šipušić J. Waste phosphogypsum - Toward sustainable reuse in calcium sulfoaluminate cement based building materials. Chem Biochem Eng Q 2013;27:219-26.

28. Leaković S, Lisac H, Vukadin R. Primjena industrijskog otpada $\mathrm{CaF}_{2}$ u procesu ozelenjivanja odlagališta fosfogipsa [Application of industrial waste $\mathrm{CaF}_{2}$ for vegetative covering of phosphogypsum disposal site, in Croatian]. Kem Ind 2012;61:505-12. doi: 10.15255/KUI.2012.001

29. Hilton J. Towards a management and regulatory strategy for phosphoric acid and phosphogypsum as co-products. In: Naturally Occurring Radioactive Material (NORM V) Proceedings of an international symposium; 19-22 March 2007; Seville, Spain. Vienna: IAEA; p. 281-95.

30. Kovler K, Perevalov A, Steiner V, Rabkin E. Determination of the radon diffusion length in building materials using electrets and activated carbon. Health Phys 2004;86:505-16. doi: 10.1097/00004032-200405000-00007

31. Kovler K. Measurements of radon exhalation rate for monitoring cement hydration. Mat Struct 2007;40:419-30. doi:10.1617/s11527-006-9149-1

32. Pravilnik o praćenju stanja radioaktivnosti u okolišu [Ordinance on environmental monitoring of radioactivity, in Croatian]. Narodne novine 40/2018.

33. European Commission (EC). Radiological protection principles concerning the natural radioactivity of building materials. Radiation Protection 112. Luxembourg: EC; 1999.

34. Abril JM, García-Tenorio R, Enamorado SM, Hurtado MD, Andreu L, Delgado A. The cumulative effect of three decades of phosphogypsum amendments in reclaimed marsh soils from SW Spain: ${ }^{226} \mathrm{Ra},{ }^{238} \mathrm{U}$ and $\mathrm{Cd}$ contents in soils and tomato fruit. Sci Total Environ 2008;403:80-8. doi: 10.1016/j.scitotenv.2008.05.013

35. Papastefanou C, Stoulos S, Ioannidou A, Manolopoulou M. The application of phosphogypsum in agriculture and the radiological impact. J Environ Radioact 2006;89:188-98. doi: 10.1016/j.jenvrad.2006.05.005

36. Mesić M, Brezinščak L, Zgorelec Ž, Perčin A, Šestak I, Bilandžija D, Trdenić M, Lisac H. The application of phosphogypsum in agriculture. Agric Conspec Sci 2016;81:713.

37. Elloumi N, Zouari M, Chaari L, Abdallah F Ben, Woodward $\mathrm{S}$, Kallel m. Effect of phosphogypsum on growth, physiology, and the antioxidative defense system in sunflower seedlings. Environ Sci Pollut Res Int 2015;22:14829-40. doi: 10.1007/ s11356-015-4716-Z 
38. Enamorado S, Abril JM, Delgado A, Más JL, Polvillo O, Quintero JM. Implications for food safety of the uptake by tomato of 25 trace-elements from a phosphogypsum amended soil from SW Spain. J Hazard Mater 2014;266:122-31. doi: 10.1016/j.jhazmat.2013.12.019

39. Council Directive 2013/59/Euratom of 5 December 2013 laying down basic safety standards for protection against the dangers arising from exposure to ionising radiation, and repealing Directives 89/618/Euratom, 90/641/Euratom, 96/29/Euratom, 97/43/Euratom and 2003/122/Euratom [displayed 22 April 2021]. Available at http://eur-lex.europa. e u / L e x U r i S e r v/ L e x U r i S e r v. do?uri=OJ:L:2014:013:FULL:EN:PDF

40. Pravilnik o uvjetima i mjerama zaštite od ionizirajućeg zračenja za obavljanje djelatnosti s izvorima ionizirajućeg zračenja [Ordinance on the conditions and measures of ionising radiation protection for performing activities involving ionising radiation sources, in Croatian]. Narodne novine 53/2018.

41. Strategija zbrinjavanja radioaktivnog otpada, iskorištenih izvora i istrošenog nuklearnog goriva [Radioactive waste, disused sources and spent nuclear fuel disposal strategy, in Croatian]. Narodne novine 125/2014.
42. Plan gospodarenja otpadom u Republici Hrvatskoj za razdoblje 2007.-2015. godine [Waste management plan of the Republic of Croatia for 2007-2015, in Croatian]. Narodne novine 85/2007; 126/2010; 31/2011; 46/2015.

43. Odluka o donošenju Plana gospodarenja otpadom Republike Hrvatske za razdoblje 2017.-2022. godine [Waste management plan of the Republic of Croatia for the Period 2017-2022, in Croatian]. Narodne novine 3/2017.

44. Council Directive 2016/52/Euratom of 15 January 2016 laying down maximum permitted levels of radioactive contamination of food and feed following a nuclear accident or any other case of radiological emergency, and repealing Regulation (Euratom) No 3954/87 and Commission Regulations (Euratom) No 944/89 and (Euratom) No 770/90 [displayed 31 May 2021]. Available at https://eur-lex.europa. $\mathrm{eu} /$ legal-content/hr/TXT/?uri=CELEX\%3A32016R0052

45. Pravilnik o obavješćivanju, registriranju i odobrenjima te prometu izvorima ionizirajućeg zračenja [Ordinance on notification, registration, approval and placing on the market of sources of ionising radiation, in Croatian]. Narodne novine $54 / 2018$.

\section{Fosfogips i njegovo potencijalno korištenje u Republici Hrvatskoj - izazovi i prilike}

Fosfogips (FG) otpadni je nusproizvod (rezidua) koji potječe iz proizvodnje fosforne kiseline i fosfatnih mineralnih gnojiva. FG je kontaminiran kemijskim i radioaktivnim tvarima, stoga se uglavnom odlaže na kontroliranim odlagalištima. U svijetu se samo oko 15 \% FG-a reciklira i ponovno koristi. U današnje vrijeme, političke i poslovne strategije stavljaju na prvo mjesto održivi razvoj kroz kružno gospodarstvo, a tu svoje mjesto može pronaći i FG. Time se stvaraju nove prilike u Republici Hrvatskoj za korištenje FG-a kao aditiva u različitim industrijama, od poljoprivrede do građevinske industrije. Zbog svojih kemijskih i radioloških svojstava, korištenje FG-a može potencijalno prouzročiti probleme za okoliš i ljudsko zdravlje. Stoga je prije korištenja nužno detaljno znanje o potencijalnim opasnostima FG-a kako bismo zaštitili ljude i okoliš. Cilj je ovoga preglednog rada sažeti dostupne podatke o FG-u u Republici Hrvatskoj, usporediti ih sa svjetskim podatcima i prepoznati nedostatke i manjak podataka o riziku koji nose potencijalno opasne tvari u FG-u. 